\title{
High Order Thinking Skills for Biology Education: Applied Microbiology Learning Videos Based on Jambi Local Wisdom
}

\author{
Retni Sulistiyoning Budiarti", Harlis, Desfaur Natalia \\ Faculty of Teaching and Education, Universitas Jambi, Indonesia \\ Received October 31, 2019; Revised January 4, 2020; Accepted January 13, 2020
}

Copyright $\mathrm{O} 2020$ by authors, all rights reserved. Authors agree that this article remains permanently open access under the terms of the Creative Commons Attribution License 4.0 International License

\begin{abstract}
Purpose: Critical thinking is needed in 21 st-century learning. The fact is that critical thinking skills are still low. Therefore, the purpose of this study is to investigate critical thinking skills using video learning based on local wisdom Jambi in microbiology courses with regular print modules. Method: Using a quantitative design quasi-experimental post-test control only. Where the total number of samples from this study were 72 biology pre-service teacher education students taken by purposive sampling technique. The experimental group (n $=36$ ) was taught with local wisdom Jambi based learning videos in applied microbiology courses, while the control group $(\mathrm{n}=36)$ was taught using traditional teaching materials. The Oliver-Hoyo Rubric for Critical Thinking (OHRCT) and the attitude questionnaire regarding cultural values are given. The data is then analyzed with the help of the SPSS 21 application to look for descriptive statistics in the form of mean, and inferential categories and statistics for the independent sample t-test. Finding: There is a significant difference in terms of critical thinking and student cap between the control class and the experimental class. It was found that by using video learning based on local wisdom Jambi obtained differences with the t-test value of 15.540 on critical thinking skills. It can be underlined that video learning based on local wisdom Jambi has a significant effect on students' critical thinking skills compared to conventional groups.
\end{abstract}

Keywords High Order Thinking, Learning Videos, Education

\section{Introduction}

Applied Microbiology is one of the elective courses that can be contacted by students of the Faculty of Biology Education, Jambi University. Studies of applied microbiology include the application of microbes in nature and their use for living things around them. The demands of this course include students being able to apply some basic microbiological techniques that support human life and well-being. Can further apply this knowledge to meet the needs of life and optimize the presence of microbes in nature (water, land, and air). The application of this field of science can be elaborated by making new innovations on the emergence of new products from the local natural wealth of Jambi through the use of computer application technology [1]; [2].

Innovation in learning is important because it plays a role in the creation of creative and skilled students amid high competition for employment as well as demands for the ability to sustain life. Creative students to innovate are students who are able to look for opportunities that are around to be changed into goods/services needed by humans [3]. One of them is the local potential that has not been maximally utilized by the people of Jambi province who live around the coast of the mangrove forest in Kuala Tungkal, for example, is a fruit preparation with the scientific name Sonneratia alba (L). Many people who only use fruit preparations to make syrup, dodol, this is due to lack of knowledge of the use of the fruit. Preparations which are the result of local potential have high economic value when processed optimally. By utilizing microbiological techniques, fruit can be used as raw material for making nata or what can be called Nata de Perepat. The product is certainly expected to be able to raise the value of the local potential of the Kuala Tungkal area in the economic sector of coastal communities [4].

For the Maker of Nata de Perepat, a special skill that is better documented is needed. This is, of course, an important study in the subject of applied Microbiology which will provide students with knowledge of the correct 
processing of Nata de Perepat. However, due to time constraints and lack of instructional media, learning is less than optimal. Besides learning is more centered on theory, this causes many students to be left behind in the correct psychomotor processes that exist at each stage of product manufacture [5]. During this learning activities only explain the production process of a product through an explanation in OHV or videos that are not validated for learning. So that it takes concrete and clear learning media as well as updates so students can understand and can understand the material.

Success in learning activities is also influenced by the use of learning media. Learning media not only helps educators in delivering a material but can also provide added value to a learning activity [6]; [7]. The National Education Association (NEA) defines that the media are printed and non-printed forms of communication such as audio-visuals and equipment. Media should be able to be manipulated, heard, seen, and read so that it can channel messages from the sender of the message to the recipient of the message, and can stimulate the thoughts, feelings, concerns, and learning interests of students so that the learning process can occur. Basically, the media are all physical tools that can present messages and stimulate students to learn. media can be in the form of books, cassettes, and film frames [8]; [9].

The use of interesting media such as learning videos can increase student interest and understanding of the stages that can be repeated at other places and times. A video is a form of learning media that can convey information clearly. According to [10]; [11] learning videos must have specific characteristics including: (1) easily stored and can be repeatedly, (2) in the presentation and storage there must be a good arrangement of orders (3) ease of operation, (4) there is a picture that presents the events of the past ago or events elsewhere. Learning videos can present information related to learning material in a consistent, accurate, quality, and can be stored to be studied again independently as needed. So students can repeat and explore the material provided.

Video is considered more suitable to be used as a learning media in applied microbiology courses, because the video can display concrete examples so that students are able to see directly the procedures for processing applied microbiology products. In addition, video is a communication medium that is very quickly captured by humans. Video is able to record and display every scene presented in detail in the form of skills relating to motion and sound that can be clarified both by slowing down, accelerating, and even repeating [12]; [13]. This can be a solution to overcome time constraints in learning microbiology.

Learning videos can be developed and designed attractively using Camtasia Studio 8 software. According to [14] Camtasia Studio is one of the multimedia software that is often used to make videos, both for film editing or video editing. This software has a complete menu so it's easy to use even for beginners. Users are very free to edit the contents of the film to be made because Camtasia can be used to import videos, pictures/photos, music. This software can also display up to dozens of editing screens so as to facilitate the editing process. Another advantage of Camtasia is being able to record screen activity, using a webcam and also recording audio that is very clear. In addition, Camtasia also has a very light capacity.

\section{Materials and Methods}

This study adopts the research [15] which is carried out in stages, namely Develop (the stage of development) and Evaluate (the stage of evaluating). Develop is carried out the stage of developing and making a learning video based on an existing flowchart and storyboard, evaluation is used along to illustrate the measurement referenced criteria that have high potential to influence the decision-making process [16].

1. Development Phase, at this stage the development and making of learning media in the form of learning videos based on local wisdom Jambi are based on existing flowchart and storyboards. In the analysis phase conducted in this study is a needs analysis, which is to find out what is needed by students in applied microbiology courses. Students need a new and innovative learning media so that they can provide examples of the application of applied microbiology and can be applied in everyday life. Furthermore, the researcher offers a solution to these problems by developing a product in the form of a learning video as a learning medium in the subject of applied microbiology using Camtasia Studio 8. The making of this learning media contains the utilization of local potential results from Kuala Tungkal namely perepat fruit as raw material for making nata. The design process translates needs into programs developed from [17].

2. The evaluation phase is carried out through several stages, namely, the evaluation carried out by a team of experts through product validation, then revising the product based on assessments and suggestions from the expert team of experts as well as evaluations conducted based on the results of product trials. If found weaknesses of the product being developed so that improvements can be made to produce learning videos that are suitable for use as learning media in applied microbiology courses.

In this study, there is content validity carried out in consultation with experts (Expert Validation Evaluation Criteria) according to their fields. The validity test in this study involved media experts. The validity of the content can be seen from the suitability of the product with the demands of the curriculum [18]. With the evaluation 
criteria as in table 1 below.

Table 1. Validation criteria

\begin{tabular}{|c|c|}
\hline Interval & Category \\
\hline $0.0-25.0$ & Very Inadequate \\
\hline $25.1-50.0$ & Not Feasible \\
\hline $50.1-75.0$ & Worthy \\
\hline $75.1-100.0$ & Very Decent \\
\hline
\end{tabular}

Construct validity, regarding the construct or structure and psychological characteristics of the aspects to be measured by the instrument. Does the construct explain differences in individual activities or behavior with respect to the aspect being measured.

The research design used by researchers is a quantitative research type quasi-experimental design using posttest-only non-equivalent control group design. That was done to investigate causal hypotheses about causes that could be manipulated by comparing one or more experimental groups that were treated with one comparison group that was not treated [19]. The design of this study was applied because it was in accordance with the objectives of the study, where the aim was to find out whether there was a difference between students' critical thinking skills using local wisdom video based on wisdom
Jambi and students using ordinary printed modules used in lectures. This researcher uses descriptive statistics in the form of mean, min and max and uses inferential statistics. The inferential statistics used are independent sample t-tests.

Table 2. Pretest-Posttest Non-Equivalent Control Group Design

\begin{tabular}{|c|c|c|c|}
\hline Group & Pretest & Treatment & Posttest \\
\hline Experimental & $\mathrm{O}_{1}$ & $\begin{array}{c}\text { Video learning based on } \\
\text { local wisdom Jambi }\end{array}$ & $\mathrm{O}_{1}$ \\
\hline Control & $\mathrm{O}_{2}$ & $\begin{array}{c}\text { Traditional learning } \\
\text { module }\end{array}$ & $\mathrm{O}_{2}$ \\
\hline
\end{tabular}

This research is located in biology education with a total of 72 students in Jambi university biology education, Jambi Province in 2019. In the experimental class, there were 36 students and in the control class, there were also 36 students. In the experimental class using video learning based on local wisdom Jambi and in the control class using traditional printed teaching materials used in lectures. The sample collection technique uses a purposive sampling method. Purposive sampling is a sampling technique based on researchers' criteria [20]. The criteria in this study are students who contract microbiology courses. Data collection procedures for referring [19], are explained in the figure below:

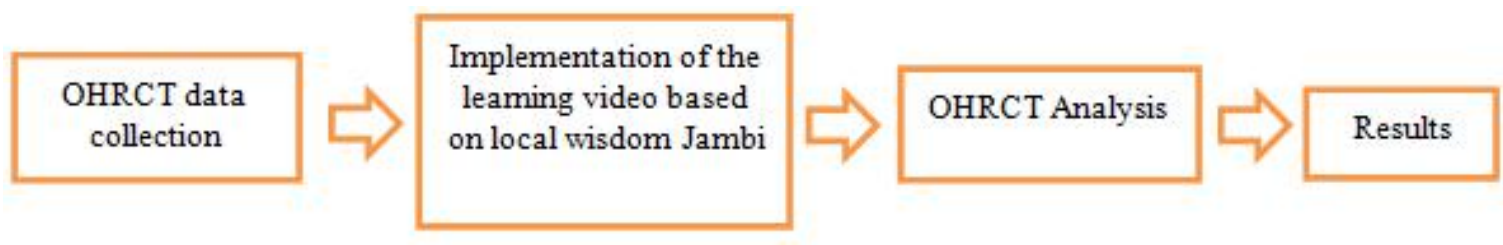

Figure 1. Research Procedure 
Based on the picture above, it can be seen that the first activity that must be carried out in the process of data collection, namely the distribution of questions to biology teacher education students in 2019. Then give action to only the experimental class by using local wisdom Jambi based learning videos, while for the control class given the traditional teaching materials of printed modules. After that, seeing the results of students' critical thinking after being given a wisdom based local wisdom Jambi video using a printed module. The instrument used was OHRCT. Students' critical thinking was adopted from Oliver-Hoyo Rubric for Critical Thinking (OHRCT). OHRCT was developed by [21], and obtained a Cronbach alpha reliability coefficient of 0.84 , which has 6 indicators, namely abstract, organization, information sources, content, relevance, and presentation.

Table 3. Indicators of Critical Thinking Skills

\begin{tabular}{|c|c|}
\hline \multirow{4}{*}{ Critical Thinking Skills } & Indikator \\
\cline { 2 - 2 } & Abstract \\
\cline { 2 - 2 } & Organization of Report \\
\cline { 2 - 2 } & Sources of Information \\
\cline { 2 - 2 } & Content of the report \\
\cline { 2 - 2 } & Relevance of Ideas \\
\cline { 2 - 2 } & Presentation \\
\hline
\end{tabular}

All data obtained from OHRCT questions in the experimental class and ordinary print modules are collected and then calculated and assisted with the SPSS 21 application. Descriptive statistics are provided to calculate frequency, percentage, average, min, and $\max$ sample [19] in the control group and experimentation. In this study, quantitative data were analyzed using parametric statistics from independent sample t-tests. Independent sample t-tests were conducted to examine the effect of attitudes on students' cultural values and critical thinking. This study uses SPSS 21 at a significance level of 0.025 .

\section{Results and Discussion}

Local wisdom based learning video Jambi is validated beforehand to the experts. The results can be seen in table 4.

From the results of the validation carried out by experts, it was found that the very feasible category for the material aspect with a level of eligibility was 87.3 , the display aspect was 89.6 with a very decent category and the language aspect had a level of eligibility. 88.5 , which means it's very feasible. Therefore, based on the results of the validation carried out by experts, it can be concluded that the video learning based on local wisdom Jambi is very feasible and good to use.

Table 4. Results from expert validation of learning videos based on local wisdom Jambi

\begin{tabular}{|c|c|c|c|}
\hline No & Aspect & Feasibility Level & Category \\
\hline 1 & Theory & 87.3 & \\
\hline 2 & Display & 89.6 & \multirow{2}{*}{ Very Decent } \\
\hline 3 & Language & 88.5 & \\
\hline
\end{tabular}

Research findings are explained in this section. The Category, and Mean results in the posttest, to show the impact of the wisdom-based local wisdom Jambi video on biology education are presented as follows.

Table 5. Gaps in Posttest critical thinking skills scores between Experiment Class and Control Class

\begin{tabular}{|c|c|c|c|c|}
\hline Aspect & Groups & Category & Mean & $\mathrm{N}$ \\
\hline \multirow{2}{*}{ Abstract } & Experiment & Good & 34.3 & 36 \\
\cline { 2 - 5 } & Control & Good & 27.9 & 36 \\
\hline \multirow{3}{*}{ Organization of Report } & Experiment & Good & 35.4 & 36 \\
\cline { 2 - 5 } & Control & Good & 27.6 & 36 \\
\hline \multirow{3}{*}{ Sources of Information } & Experiment & Good & 32.4 & 36 \\
\cline { 2 - 5 } & Control & Good & 29.1 & 36 \\
\hline \multirow{3}{*}{ Conten of the report } & Experiment & Good & 33.2 & 36 \\
\cline { 2 - 5 } & Control & Good & 28.4 & 36 \\
\hline \multirow{2}{*}{ Relevance of Ideas } & Experiment & Good & 28.3 & 36 \\
\cline { 2 - 5 } & Control & Good & 29.8 & 36 \\
\hline \multirow{2}{*}{ Presentation } & Experiment & Good & 33.1 & 36 \\
\cline { 2 - 5 } & Control & Good & 28.5 & 36 \\
\hline
\end{tabular}

Based on table 5, we can see that the experimental group students were superior in all indicators compared to the control group students. Overall, we found a significant difference between the scores of the two groups after treatment by looking at the Mean values. Furthermore, the experimental group students received the highest average rating in the Report Organization $(\mathrm{M}=35.4)$ and the lowest in Relevance of ideas $(M=28.3)$ The control group students received the highest average rating in Relevance of ideas $(M=29.8)$ and the lowest in Report Organizations ( $\mathrm{M}=27.6)$.

Table 6. Independent sample t-test for students' critical thinking skills

\begin{tabular}{|c|c|c|c|c|c|c|}
\hline & \multirow{2}{*}{$\mathrm{T}$} & \multirow{2}{*}{ Df } & \multirow{2}{*}{ Mean } & \multirow{2}{*}{ Std.Deviation } & \multicolumn{2}{|c|}{ 95\% confidence interval } \\
\hline & & & & & Lower & Upper \\
\hline \multirow{2}{*}{ Critical thinking skills } & 15.543 & 72 & 3.1906 & .14321 & 18.236 & .6120 \\
\hline & 15.543 & 88.067 & 2.3033 & .20015 & 17.935 & .8615 \\
\hline
\end{tabular}


From table 6 it can be seen that the value obtained (t arithmetic) with the value of $t$ table. T-table values can be found in the $t$ table with a significance value of 0.025 (2-sided test) with a degree of freedom (df) 72. In this study, the results for t table are 1.66629. Whereas the value of $t$ arithmetic can be seen in Table 6. (column t) which is 15.543 . The hypothesis testing criterion is the value of rejection of $\mathrm{H} 0$ [22]. So, it can be concluded that there are significant differences in attitudes towards student cultural values between control classes taught using traditional teaching materials and experimental classes using local wisdom Jambi based learning videos in applied microbiology courses. It can be seen from Table 6 that the average value of student interest is 3.1906, which means it can improve the attitudes of students in learning cultural values.

In making the learning video it is necessary to add skills that are expected to exist in the 21st-century education so that the video can explore students' abilities and provide input and experience for other students. There needs to be a solid match of learning videos with models and delivery methods when the learning videos are used [23]; [24]; [25].

The lecturer is one who must participate in building student understanding. The participation of lecturers must be limited to the role of facilitators and student learning partners, for example presenting situations that make students think critically on the authentic problems of material through the application of concepts and facts [26]; [27]. This tendency can make curiosity in various things around it so that there is giving meaning. Developing the ability of initiative, critical thinking, and creative will direct students to be people who are able to make decisions and can solve a problem they face.

The ability to think is one that must be possessed by a student as a provision in facing the development of science and technology in the current era. The ability of a person to succeed in his life, among others, is determined by the ability to think, especially in solving a problem he faces [28]. Besides the ability to think is also a means to achieve educational goals that is that students are able to solve problems that are so difficult or high level [29]. One of the goals of video learning methods is so that students can solve problems that are around their environment. The thinking skills presented in this study include the media and critical thinking skills.

In essence, learning is a process of interaction between students and their environment, so that behavior changes occur in a better direction for a long period of time. The existence of a video about the use of Perepat fruit as the basic material of Nata through video display makes students construct meaning, discourse, dialogue, experience and relate it to experiences or information that have been learned [30]; [31]. In addition, learning by developing experience and viewing videos that display work procedures will produce knowledge that is easy to remember and lasts long. Thus, it is hoped that applied microbiology learning will be more meaningful and critical thinking.

The ability to think critically is one of the intellectual capital that is very important for every student. The ability to think critically is a fundamental part of human maturity. Critical thinking is thinking reasoned and reflective by emphasizing decision making about what to believe and do [32]. Critical thinking is an activity of analyzing ideas or ideas towards more specific, sharply differentiating, choosing, identifying, making procedures, studying, and developing towards more perfect [33].

\section{Conclusions}

It can be seen that the results of students' critical thinking skills as well as having a good category. On the results of students' critical thinking skills for the control class that uses traditional teaching materials there are significant differences with the experimental class that uses learning videos based on local wisdom Jambi who are in superior experimental class because they use video learning models based on local wisdom Jambi in microbiology courses with scores t-test 15.543 on critical thinking. According to the results, it is recommended that pre-service teachers need to be given the opportunity to develop direct experience and thoughts in lecture activities. The lecturers must utilize learning media such as learning videos to develop various learning skills from students.

\section{Acknowledgments}

The researcher would like to thank the chief of Biology Department Universitas Jambi.

\section{REFERENCES}

[1] Astalini., Kurniawan, D. A., Sulistiyo, U., Perdana, R., Susbiyanto, S. E-Assessment Motivation in Physics Subjects for Senior High School. International Journal of Online and Biomedical Engineering (iJOE). 15(9), 4-15. 2019.

[2] Astalini., Darmaji., Kurniawan, W., Khairul, A., \& Kurniawan, D. A. Effectivenes of Using E-module and E-Assessment. International Journal of Interactive Mobile (IJIM), 13(9), 21-39. 2019.

[3] Aktekin, N. C. Critical Friends Group (CFG): Inquiry-Based Professional Development Model for Turkish EFL Teachers. Eurasian Journal Educational Research. 81, 1-20. 2019

[4] Syahrial., Asrial., Kurniawan, D. A., Nugroho, P., Septiasari, R., Pratama, R. A., Perdana, R. Increased Behavior of Students' Attitudes to Cultural Values Using the Inquiry Larning Model Assisted by 
Ethnoconstructivism. Journal of Education Science and Technology (EST). 5(2), 166-175. 2019.

[5] Andrini, V. S. The effectiveness of inquiry learning method to enhance students' learning outcome: A theoretical and empirical review. Journal of Education and Practice, 7(3), 38-42. 2016.

[6] Asrial., Syahrial., Kurniawan, D. A., Chan, F., Septianingsih, R., Perdana, R. Multimedia Innovation 4.0 in Education: E-Modul Ethnoconstrucivism. Universal Journal of Educational Research. 7(10), 2098-2107, 2019.

[7] Astalini, A., Darmaji, D., Kurniawan, D. A., Melsayanti, R. E-Assessment of Student Perception of Natural Science Based on Seska in Middle School Students in Indonesia. International Journal of Scientific \& Technology Reseaerch, 8(9), 858-863. 2019.

[8] Aybek, B., \& Aslan, S. An Analysis of the Units "I'm Learning my Past" and "The Place Where We Live" in the Social Studies Textbook Related to Critical thinking Standars. Eurasian Journal Educational Research. 65, 35-54. 2016.

[9] Cetin, Y., Mirasyedioglu, S., \& Cakiroglu, E. An Inquiry into the Underlying Reasons for the Impact of Technology Enhanced Problem-Based Learning Activities on Students' Attitudes and Achievment. Eurasian Journal Educational Research. 79, 191-208. 2019.

[10] Ezer, H., Gilat, I \& Sagee, R. Perception of teacher education and professional identity among novice teachers. European Journal of Teacher Education. 33(4).: 391-404. 2010. DOI: $10.1080 / 02619768.2010 .504949$

[11] Gillette, CM Consideration of Problem-Based Learning in Athletic Training Education. Athletic Training Education Journal, 12 (3), 195-201. 2017.

[12] Kaewkiriya, T. "A Design And Development Of E Learning Content For Multimedia Technology Using Multimedia Game". International Journal of Software Engineering \& Applications (IJSEA), 4(6), 61, 2013.

[13] Kunnari, I., \& Ilomäki, L. Reframing teachers' work for educational innovation. Innovations in Education and Teaching International, 53(2), 167-178, 2016.

[14] Kyriakides, L. \& Creemers, B. P. M. "Using a Multidimensional Approach to Measure the Impact of Classroom Level Factors upon Student Achievement: a Study Testing the Validity of the Dynamic Model”. School Effectiveness and School Improvement, 19(2), 183-205. 2008.

[15] Thiagarajan, S., Semmel, D. S., \& Semmel, M. I. Instructional development for training teachers of exceptional children. 1974.

[16] Ivers, K. S., \& Barron, A. E. Multimedia Project in Education: Designing, Producing, and Assessing. USA: Libraries Unlimited. 2002.

[17] Branch, M, B. Instructional Design: The ADDIE Approach. USA: University Of Georgia. 2009.

[18] Cohen, L., Manion, L., \& Morrison, K. Research Methods In Education : Routledge. 2005

[19] Creswell, John W. Educational Research: Planning,
Conducting, And Evaluating Quantitative And Qualitative Research. New York: Pearson, 2012.

[20] Kerlinger, F. N. Foundations of behavioral research. Yogyakarta: Gadjah Mada, 2014.

[21] Oliver-Hoyo, M. T. Designing a written assignment to promote the use of critical thinking skills in an introductory chemistry course. Journal of Chemical Education, 80(8), 899-903. 2003

[22] Cramer, D. Advanced quantitative data analysis. McGraw-Hill Education (UK), 2003.

[23] Darmaji., Kurniawan, D. A., Astalini., Lumbantoruan, A., \& Samosir, S. C. Mobile Learning In Higher Education For The Industrial Evolutioin 4.0: Perception and Response of Physics Practicum. International Journal of Interactive Mobile (IJIM), 13(9), 4-20, 2019.

[24] Maison, Darmaji, Astalini, Dwi Agus Kurniawan, Peni Sefiah Indrawati. Science Process Skills And Motivation. Humanities \& Social Science Reviews (HSSR), 7(5), 48-56, 2019.

[25] Maison., Astalini., Kurniawan, D. A., Perdana, R., Anggraini, L. The Phenomenon of Physicology Senior High School Education: Relationship of Students' Attitudes towards Physics, Learning Style, Motivation. Universal Journal of Educational Research. 7(10), 2199-2207, 2019.

[26] Boonjeam W., Tesaputa K., \& Sri-ampai A. Program development for primary school teachers' critical thinking. International Education Studies, 10(2), 131-138, 2017.

[27] Kabeel, A. R., \& Eisa, S. A.-M. The correlation of critical thinking disposition and approaches to learning among baccalaureate nursing student. Journal of Education and Practice, 7(32), 91-103, 2016.

[28] Bansal, D. "Benefits Of Ict In Education". Bhartiyam International Journal Of Education \& Research. 5(2), 160-167, 2016.

[29] Bulunuz, Mizrap. The Role of Playful Science in Developing Positive Attitudes Towards Teaching Science in a Science Teacher Preparation Program. Eurasian Journal Educational Research. 58, 67-88, 2015.

[30] Dobber, M., Vandyck, I., Akkerman, S, Graaff, D, R, Beishuizen, J., Pilot, A., Verloop, N \& Vermunt, J. The development of community competence in the teacher education curriculum. European Journal of Teacher $\begin{array}{llll}\text { Education, } & 36(3): & 346-363, & \end{array}$ DOI: $10.1080 / 02619768.2012 .718326$

[31] Duran, M., \& Dökme, I. The effect of the inquiry-based learning approach on student's critical-thinking skills. Eurasia Journal of Mathematics, Science and Technology Education, 12(12), 2887-2908, 2016.

[32] Fu, J.S. "ICT in Education: A Critical Literature Review and Its Implications" International Journal of Education and Development using Information and Communication Technology (IJEDICT), 9(1), 112-125, 2013.

[33] Jadhav, V. "ICT and Teacher Education". International Educational E-Journal, 1(1), 64-69, 2011. 